\title{
Insights into English Non-Major Students' Learning Autonomy at Thai Nguyen University
}

\author{
Nguyen Thi Dieu Ha \\ School of Foreign Languages - Thai Nguyen University, Viet Nam
}

\begin{abstract}
The study aims at exploring teachers and students' perceptions towards learning autonomy, and how the learning autonomy affects their English language proficiency. The understanding of learning autonomy will help teachers apply appropriate pedagogical solutions for their students. The results show that participants seemed to have some aspects of autonomous learning, so they are considered as autonomous learners. Furthermore, learning autonomy correlated with teachers' objectives and requirements, learning styles and learning strategies significantly. The highest correlation is for the relationship between learning autonomy and teachers' objectives and requirements, followed closely by the association with learning styles and learning strategies. Hence, it is suggested that, the higher being awareness of understanding teacher's purposes and requirements and better understanding how to create learning styles and adjust learning strategies students are, the more autonomous they are.

Key words: learning autonomy, language learning, language proficiency
\end{abstract}

\section{INTRODUCTION}

It is undeniable that English is important in the world today. English has become the language of commerce, diplomatic, politics, education and sciences. However, the teaching and learning of English reveal problems. Most of the students at all education levels in Vietnam study English for 6 to 10 years or even more, however, their uses of English for real communication are limited. There are many reasons for the problem, but the teaching and learning methods are the key issues. In this study, the researcher focuses more on the side of learners i.e., how the learners see the language and how they approach the learning and language learning.

Psychologically, the learning process occurs when one feels the world through hearing, seeing and other senses. The information goes to short-term memory (STM) then is transmitted to long-term memory (LTM) where it is stored for a lifetime. However, there must be some mechanisms for the transmission from STM to LTM to occur (Petty, 2009). The learning is then developed to higher levels such as how to use the information stored in the LTM for other purposes. This is summarized in Bloom's taxonomy as knowledge, comprehension, application, analysis and synthesis (Bloom, 1956).

Language learning is not excluded from theories of learning. The so-called first language (L1) acquisition refers to how a child picks up his/her mother tongue. This process occurs automatically provided that the child is not suffered from any physical disorder. However, the learning of a second (L2) or a foreign language (FL) is quite different from that of the first language. It requires learners a great deal of effort.

Language learning and teaching methods have seen many innovations from grammar-translation which focuses on form to communicative language teaching (CLT) which focuses on meaning. The basic principles of CLT emphasize the roles of learners which have been shifted from passively received information from teachers to actively find the information from peers, other sources for their deep understanding. In order to be benefited from resources available, learners should become 'self-instruction', 'selfaccess', 'self-study', 'self-education' learners. In other words, 'the autonomous learner' is what a student should become. Richards (2006: 4) notes that:

"The type of classroom activities proposed in CLT also implied new roles in the classroom for teachers and learners. Learners now had to participate in classroom activities that were based on a cooperative rather than individualistic approach to learning. Students had to become comfortable with listening to their peers in group work or pair work tasks, rather than relying on the teacher for a model. They were expected to take on a greater degree of responsibility for their own learning. And teachers now had to assume the role of facilitator and monitor." 


\section{Insights into English Non-Major Students' Learning Autonomy at Thai Nguyen University}

\section{Research questions}

The study aims to investigate students' perceptions toward learners' learning autonomy at School of Foreign Languages Thai Nguyen University (SFL-TNU). The study tries to answer the following research questions:

- What are students' perceptions towards their learning autonomy?

- To what extent does learning autonomy affect English language proficiency?

\section{LITERATURE REVIEW}

\subsection{Theories of language learning}

Languages in general and English language in particular have been the focus of language teaching methodologies for decates. Mayer (2002) defines learning as a process that leads to change, which occurs as a result of experience and increases the potential for improved performance and future learning. The theories of language learning stem from theories of learning which include behaviourism, cognitivisism, and constructivism.

\subsubsection{Behaviorism}

Behaviourism is a theory of learning focusing on observable behaviours and discounting any mental activity. Learning is defined simply as the acquisition of new behaviour. Behaviourists call this method of learning 'conditioning'. Two different types of conditioning are described and demonstrated as viable explanations of the way in which animals and humans alike can be 'taught' to do certain things. Behaviourists define learning as a relatively permanent change in behaviour as the result of experience. This change in behaviour is always observable, with some behaviourists proposing that if no observable change happens, no learning has occurred (Jordan, A. et.al. 2008: 22).

Woodlard (2010: 1) claims that:

"Behaviourism is a theory of animal and human learning that focuses upon the behaviour of the learner and the change in behaviour that occurs when learning takes place. Learning in the context of behaviourism can be defined as the acquisition of a new behaviour or the modification of behaviour as a result of teaching, training or tutoring. Learning is demonstrated by the behaviour of the learner in their actions or reactions to further stimulus."

\subsubsection{Cognitivism}

Cognitive theories stress the acquisition of knowledge and internal mental structures and, as such, are closer to the rationalist end of the epistemology continuum (Bower \& Hilgard, 1981). Learning is equated with discrete changes between states of knowledge rather than with changes in the probability of response. Cognitive theories focus on the conceptualization of students' learning processes and address the issues of how information is received, organized, stored, and retrieved by the mind. Learning is concerned not so much with what learners do but with what they know and how they come to acquire it (Jonassen, 1991b). Knowledge acquisition is described as a mental activity that entails internal coding and structuring by the learner. The learner is viewed as a very active participant in the learning process.

Cognitivism involves the study of mental processes such as sensation, perception, attention, encoding and memory. Cognitivists believe that learning results from organizing and processing information effectively. Cognitivists believe that learning results from organizing and processing information effectively. If educators understand how learners process information, they can design learning experiences that optimize this activity. For example, an awareness of how learners transfer short-term memories into meaningful knowledge is likely to be useful in the classroom. (Jordan, 2008: 36).

\subsubsection{Constructivism}

Constructivism is a theory that equates learning with creating meaning from experience (Bednar et. al., 1991). Even though constructivism is considered to be a branch of cognitivism (both conceive of learning as a mental activity), it distinguishes itself from traditional cognitive theories in a number of ways.

Constructivists do not share with cognitivists and behaviorists the belief that knowledge is mind-independent and can be 'mapped' onto a learner. Constructivists do not deny the existence of the real world but contend that what we know of the world stems from our own interpretations of our experiences. Humans create meaning as opposed to acquiring it. Since there are many possible meanings to glean from any experience, we cannot achieve a predetermined, "correct" meaning. Learners do not transfer knowledge from the external world into their memories; rather they build personal interpretations of the world based on individual experiences and interactions. Thus, the internal representation of knowledge is constantly open to change; there is not an objective reality that learners strive to know. Knowledge emerges in contexts within which it is relevant. Therefore, in order to understand the learning which has taken place within an individual, the actual experience must be examined (Bednar et. al., 1991).

\subsection{The language learners}

It is a fact that not all individuals acquire a second language (L2) in the same way or with the same degree of success. The outcome of language learning depends heavily on three pillars namely the learners, the teachers and the learning environment. Naiman et. al. (1978) summarized numbers of variables that make up a good language learner. (See figure 1) 


\section{Insights into English Non-Major Students' Learning Autonomy at Thai Nguyen University}

The factors of teaching and language learning environment are not mentioned in this study. We just examine the learner's variables to find the importance of this pillar towards the language outcome. By looking at the diagram, we see that language learner variables consist of cognitive and affective factors.

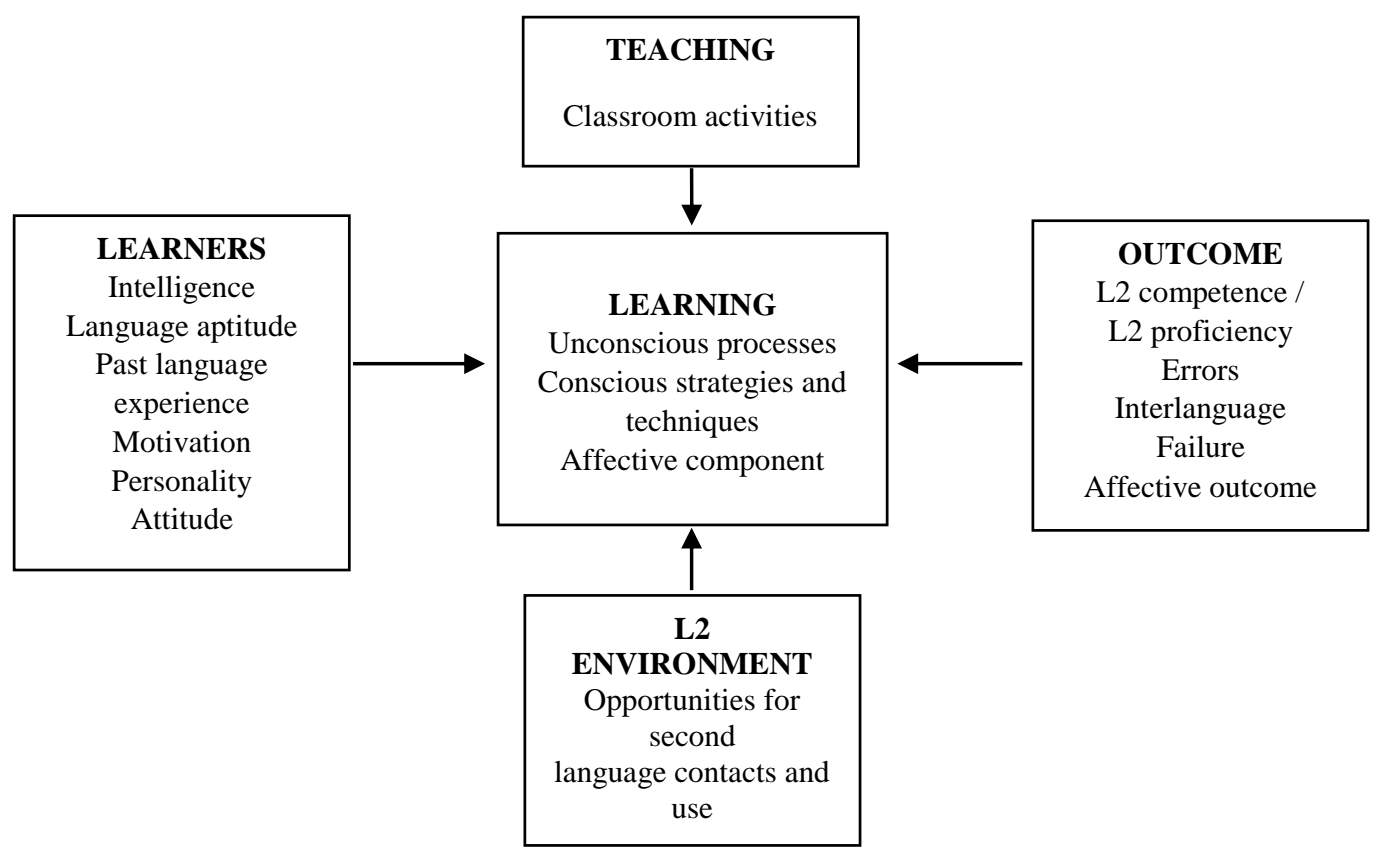

Figure 1. Model of second language learning (Naiman, 1978: 3)

\subsubsection{Cognitive factors}

The role of intelligence in good language learners (GLLs) is a highly debated topic. It is difficult to measure in classroom studies, because a person's intelligence is complex, and "individuals have many kinds of abilities and strengths, not all of which are measured on traditional IQ tests" (Lightbown, 2001:31). Since researchers have difficulty measuring the different facets of intelligence, it is equally difficult to analyze how it relates to GLLs. Some research suggests that intelligence relates to certain types of language learning. Research performed by Genessee (cited in Lightbown, 2001:31) indicates that while intelligence does alter reading grammar and vocabulary skills, it does not affect oral communicative skills. Since oral skills play a major role in many modern language classrooms, the importance of intelligence in those learning environments is lessened. Another reason that intelligence and aptitude are largely viewed as irrelevant is because they cannot be altered to aid students in acquiring a new language. Rubin notes that aptitude is the learning variable that is least susceptible to manipulation (1975:44). Since intelligence cannot be altered to aid students become more successful learners, it is largely irrelevant for pedagogical purposes.

\subsubsection{Affective factors}

Most researchers now agree that the affective factors in second language acquisition are the most crucial. A learner's personality, motivation, beliefs, age, class, ... all appear to be significant (Mitchell, 2001:25).

While a person's intelligence seems to correlate with grammatical and metalinguistic knowledge, comparisons of studies indicate that personality relates to communicative ability (Lightbown, 2001:33). This can be seen in self-confident students. These students readily interact with those around them. These interactions allow them to recall information and apply it to the conversational settings. Language ambiguity tolerance is another personality trait commonly found in GLLs. Naiman (1978:147) suggests that "those students who have a high intolerance of ambiguity may have great difficulty in coping with the amount of ambiguity present in the second language classroom". The students that are ambiguity-tolerant are better able to analyse the differences between L1 (the first language) and L2.

\subsubsection{Motivation}

Learners in general and language learners in particular should be motivated to be great achievers. Motivation concerns what moves a person to make certain choices, to engage in action, and to persist in action (Griffiths, 2008:19). In addition, Gardner and Lambert argued that language learning motivation was qualitatively different from other forms of learning motivation, since language learning entails much more than acquiring a body of knowledge and developing a set of skills (Gardner \& Lambert, 1972). The language learner must also be willing "to identify with members of another ethnolinguistic group and to take on very subtle aspects of their behavior, including their distinctive style of speech and their language" (Gardner \& Lambert, 1972:135). 


\section{Insights into English Non-Major Students' Learning Autonomy at Thai Nguyen University}

Apart from teaching and second language learning environment, the language learners play an important part for the language outcome. Motivation has been seen as the key variable for successful language learners. Dornyei, Z. \& Ryan, S. (2015:65) when investigated about psychology of language learners concluded that:

"Motivation provides the primary impetus to initiate L2 learning and later the driving force to sustain the long and often tedious learning process; indeed, all the other factors involved in SLA presuppose motivation to some extent. Without sufficient motivation, even individuals with the most remarkable abilities cannot accomplish long-term goals, and neither are appropriate curricula and good teaching enough on their own to ensure student achievement."

\subsection{Learning autonomy}

\subsubsection{The nature of autonomy in language learning}

The term autonomy has being increasingly used in the educational field since last century and has become an important element in education. It is seen today as an effective alternative to traditional education that has greatly enriched educational practice. It would be an impossible task to write an exhaustive list of the social contingencies and currents of thought which contributed to the inception and the increased attention of autonomy in education.

In formal educational contexts, the basis of learner autonomy is acceptance of responsibility for one's own learning; the development of learners autonomy depends on the exercise of that responsibility in a never-ending effort to understand what one is learning, why one is learning, how one is learning, and with what degree of success; and the effect of learner autonomy is to remove the barriers that so easily erect themselves between formal learning and the wider environment in which the learner lives.

\subsubsection{Learner autonomy}

While it is not known when the term 'learner autonomy' was first used as pedagogy, it appeared officially for the first time in second language education in the Council of Europe Modern Languages Project in 1979 by Holec. This led to the publication of Holec's (1981:3) seminal report, in which he defined learner autonomy as "the ability to take charge of one's own learning". In this definition, Holec treated learner autonomy as an attribute of the learner. Following this, various other definitions of learner autonomy have been used. For example, Wenden (1999) indicated the importance of metacognitive awareness when she claimed that true learner autonomy refers to how students reflect on their learning and how they are able to realise when they have effective learning opportunities. In another example, Littlewood (1996: 427) took the notion of autonomy as "learners' ability and willingness to make choices independently". He argued that "this capacity depends on two main components: ability and willingness" (p.428). These two abilities are interdependent and are divided into subcomponents of knowledge about the alternative choices and skills available for carrying out appropriate choices. Willingness depends on the motivation and confidence a person has in order to take responsibility for necessary choices. In order to become autonomous successfully, a person needs to have the four subcomponents of knowledge, skills, motivation, and confidence. Littlewood (1996) also suggested that these components be focused in the development of learner autonomy.

There exists so many definitions and interpretations of learner autonomy that Benson (2009) described three metaphors for three strategies that researchers have employed to define learner autonomy. The first metaphor is the: "the kaleidoscopic strategy" (p. 18) which is used when the researchers accept all previous and current definitions about learner autonomy equally, and then makes a macro-definition. The second strategy is called "the exegetical" (p. 19). Using this strategy, researchers go back to an earlier source (such as Holec's), interpret it and argue that this interpretation represents the core meaning. This can be seen clearly in the research that uses Holec's original definition, like Benson's (1997). The third strategy is the "quintessential strategy" which involves an attempt to try to discover and/or isolate, what is most essential to learner autonomy. For instance, Little (2007) combines his own definition (Little, 1995) with that of Holec (1981). According to Benson (2009) the third strategy is 'clearly the strongest of the three.'

\subsection{Learner autonomy in language learning \\ 2.4.1 Personal autonomy}

Relying on a broad concept of personal autonomy put forth by liberal philosophers, Benson (2008) argues that most individuals have a tendency toward autonomy and that human beings attach great importance to having freedom in making choices and setting goals. He concludes that this desire is also shared by teachers and learners and makes them interested in the concept of learner autonomy. Benson's view of the inclination to autonomy is similar to Little's (2009) view of the autonomous nature of human beings. Little (2007: 19) suggests that from birth, human beings have a "willful agency, demands and personal agenda". The desire for protecting and practicing one's autonomy grows within human beings and manifests itself through different aspects of life including education. However, with regards to language learner autonomy, there exist certain barriers such as teacher or learner resistance put in place for various reasons which will be explored in the following sections. Benson (2008) highlights the importance of learning about the perspectives held by teachers and learners on learner autonomy. Moreover, he emphasizes that learners and teachers do not necessarily share the same perspectives. Teachers, Benson argues, focus more on the institutional aspect of learner autonomy with classroom arrangements in place and the students taking charge of the responsibilities determined and established therein. The learners, on the other hand, hold a broader view of learner autonomy. To learners, autonomy is concerned with their lives beyond their classrooms. 


\section{Insights into English Non-Major Students' Learning Autonomy at Thai Nguyen University}

\subsubsection{Teachers' perspectives}

Teachers' perspectives of language learner autonomy to a large extent have been affected and informed by different interpretations of learner autonomy proposed by theoreticians. Such interpretations have been at times controversial and extreme. Among such controversies, one can refer to a classic dilemma about learner autonomy regarding its nature. Benson (2008) describes as classic yet false an argument regarding the development of learner autonomy as a goal of education being either product oriented or process oriented. The argument as Benson suggests maintains a dichotomy between those who favor the process oriented nature of the development of learner autonomy encouraging situational freedom where learners can enjoy their autonomy and freedom in their education within the process and the other extreme which supports the idea that the development of learner autonomy should be product-oriented. According to the latter group, the strategies employed to promote language learner autonomy do not necessarily provide situational freedom for the learners during the process, but rather are activities that will ultimately lead to the production of autonomous learners.

\subsubsection{Learners' perspectives}

As with the case of the teachers' perceptions, an important issue to note about exploring beliefs is that perceptions are based on unique individual evaluations and judgments meaning that the researcher needs to infer the underlying concepts expressed as beliefs (Henry, 2014). Individuals' perceptions and beliefs as mentioned previously in citations from Bandura $(1977,1986)$ and Barcelos (2003) shape their world and identity and inform their actions and behavior including the educational ones. Accordingly, the views held by learners about language learner autonomy and how positive it can be for their learning does indeed impact on whether learners will embrace it or on the contrary develop some degree of aversion toward it.

2.4.4 Self-regulation

Henry (2014) describes self-regulation as the process through which individuals draw upon their resources including cognitive, behavioral and affective to realize their learning goals. Self-regulation houses both activities that facilitate learning as well as "beliefs about learning such as positive thoughts about the capacity to learn" (Henry, 2014:101). Zimmerman (1998) highlights three major stages associated with self-regulation as a process, namely forethought, performance or volitional control, and self-reflection. According to Okazaki (2012), forethought involves cognitive processes utilized to facilitate the actual learning. These processes include "goal setting, reflection on previous learning, self-efficacy beliefs, strategic planning, and raising intrinsic interest” (Okazaki, 2012: 22-23).

\subsubsection{Self-efficacy}

As mentioned above, learners have the ability to condition their beliefs about learning and consequently the behavior pertaining to learning. Bandura (1997) describes as self-efficacy the beliefs and judgments held by an individual about their capability to successfully perform different tasks including learning. The emphasis on the individual agency by both language learner autonomy and self-efficacy beliefs reveals the direct relationship between the two constructs. Furthermore, self-efficacy serves as the infrastructure for motivation (Henry, 2014). To support his opinion, Henry (2014) cites Pajares (2008) suggesting that individuals will not be motivated to initiate a process unless they believe that they have the ability to succeed in the given task. An important consideration is the impact of prior experience manifested in the individuals' self-evaluation upon self-efficacy beliefs. Individuals' past experiences and the outcomes of their previous actions to a large extent shape the picture learners have of their competence in a given field.

\subsubsection{Self-determination}

Another theory relevant to language learner autonomy and the current research is that of self-determination theory (SDT). Described as the graded internalization of external motives, SDT is deeply related to learner autonomy and motivation as two interrelated constructs (Okazaki, 2012). To have a thorough understanding of self-determination theory, an understanding of extrinsic and intrinsic categorization of motivation is essential.

\section{METHODOLOGY}

The study employs a quantitative research design in order to investigate the students' perceptions on their learning autonomy, and more importantly to figure out the factors influencing the autonomous learners in learning English.

\subsection{Participants}

The study involved 103 English non-major students who were studying at School of Foreign Languages - Thai Nguyen University.

\subsection{Instrument}

The questionnaire gathering data from students' perceptions about learning autonomy consisted of two main parts. The first part asking for background information consisted of 3 questions. In this section, students were asked about their personal information: full name, gender, age, year of learning English and English language proficiency. In the second part, students were asked to circle the alternative (SD- Strongly disagree; D-Disagree; N- Neutral; A - Agree and SA - Strongly agree ) in the total of 19 Likert- scale questions in order to gather their opinions about their learning autonomy. The questionnaire was administered at the end-year course during the summer of 2019. 


\section{Insights into English Non-Major Students' Learning Autonomy at Thai Nguyen University}

\subsection{Data analysis procedure}

The participants' responses for two sections were collected and then keyed in SPSS version 23. In the first section, each of the variables corresponding to the students' demographic was converted into the percentage. In the second section, descriptive statistics analysis was employed by calculating the mean scores for each item in the second section of the questionnaire. More importantly, T-test was used to analyse the items related to student's perceptions on learning autonomy as well as factors affecting learners' autonomy.

\section{FINDINGS AND DISCUSSIONS}

\subsection{Students' overall perceptions}

During the analysis procedure, descriptive statistics analysis was made by computing the overall mean score of all 19 questions (Q.1-Q.19) in order to investigate the overall perceptions on students' autonomy. Table 1 shows overall mean scores for students' perceptions of all items.

Table 1. Overall mean of students' perceptions

\begin{tabular}{|l|l|l|}
\hline $\mathrm{N}$ & Overall mean & Std. Deviation \\
\hline 103 & 3.7303 & .757581 \\
\hline
\end{tabular}

Table 2. Rating scale for interpreting Likert-Scale responses

\begin{tabular}{|l|l|l|}
\hline Mean & Degree & Opinion \\
\hline $4.5-5.0$ & Very high & Strongly agree \\
\hline $3.5-4.4$ & High & Agree \\
\hline $2.5-3.4$ & Moderate & Neutral \\
\hline $1.5-2.4$ & Low & Disagree \\
\hline $1.1-1.4$ & Very low & Strongly disagree \\
\hline
\end{tabular}

From Table 1 and 2, the average mean of students' perceptions is 3.7303 which are closer to high than very high. Therefore, it can be assumed that the students' perceptions of the learning autonomy were on the whole highly positive $(\mathrm{M}=3.66, \mathrm{SD}=0.757)$. More specifically, the results obtained for each question in the questionnaire were analyzed and reported independently thr ough frequencies and percentage analyses using SPSS program. Table 4 shows the summary of the descriptive statistic results for Q.1Q.19.

Table 3. Summary of the descriptive statistic results for Q1-Q19 (N=103)

\begin{tabular}{|c|c|c|c|c|c|c|c|c|c|c|}
\hline \multirow[t]{2}{*}{ Items } & \multicolumn{2}{|c|}{ SD } & \multicolumn{2}{|l|}{ D } & \multicolumn{2}{|l|}{$\mathbf{N}$} & \multicolumn{2}{|l|}{$\mathbf{A}$} & \multicolumn{2}{|c|}{ SA } \\
\hline & $\mathrm{n}$ & $\%$ & $\mathrm{n}$ & $\%$ & $\mathrm{n}$ & $\%$ & $\mathrm{n}$ & $\%$ & $\mathrm{n}$ & $\%$ \\
\hline $\begin{array}{l}\text { Q.1: I understand the teacher's teaching } \\
\text { objectives and requirements. }\end{array}$ & 2 & 1.9 & 1 & 1 & 38 & 36.9 & 59 & 57.3 & 3 & 2.9 \\
\hline $\begin{array}{l}\text { Q.2: I know the teacher's purpose of employing } \\
\text { some learning activities to improve students' } \\
\text { language skills. }\end{array}$ & 2 & 1.9 & 8 & 7.8 & 32 & 31.1 & 58 & 56.3 & 3 & 2.9 \\
\hline $\begin{array}{l}\text { Q.3: I am able to set up English language } \\
\text { learning objectives. }\end{array}$ & 1 & 1 & 3 & 2.9 & 36 & 35 & 57 & 55.3 & 6 & 5.8 \\
\hline $\begin{array}{l}\text { Q.4: I can realize my English language learning } \\
\text { objectives. }\end{array}$ & 3 & 2.9 & 10 & 9.7 & 27 & 26.2 & 53 & 51.6 & 10 & 9.7 \\
\hline Q.5: I make a time plan to study English. & 5 & 4.9 & 2 & 1.9 & 24 & 23.3 & 64 & 62.1 & 8 & 7.8 \\
\hline $\begin{array}{l}\text { Q.6: I can make a study plan according to my } \\
\text { situation. }\end{array}$ & 1 & 1 & 2 & 1.9 & 30 & 29.1 & 57 & 55.3 & 13 & 12.6 \\
\hline Q.7: I adjust my study plan if necessary. & 2 & 1.9 & 3 & 2.9 & 22 & 21.4 & 61 & 59.2 & 15 & 14.5 \\
\hline $\begin{array}{l}\text { Q.8: I understand foreign language learning } \\
\text { strategies in general. }\end{array}$ & 0 & 0 & 2 & 1.9 & 35 & 34 & 53 & 51.5 & 13 & 12.6 \\
\hline $\begin{array}{l}\text { Q.9: I use listening strategies when I practise } \\
\text { my listening skills. }\end{array}$ & 0 & 0 & 2 & 1.9 & 35 & 34 & 58 & 56.3 & 8 & 7.8 \\
\hline $\begin{array}{l}\text { Q.10: I use communicative strategies when I } \\
\text { practise my oral English. }\end{array}$ & 2 & 1.9 & 0 & 0 & 41 & 39.8 & 50 & 48.5 & 10 & 9.7 \\
\hline
\end{tabular}


Insights into English Non-Major Students' Learning Autonomy at Thai Nguyen University

\begin{tabular}{|l|l|l|l|l|l|l|l|l|l|l|}
\hline $\begin{array}{l}\text { Q.11: I use writing strategies when I write in } \\
\text { English. }\end{array}$ & 1 & 1 & 3 & 2.9 & 32 & 31.1 & 55 & 53.4 & 12 & 11.7 \\
\hline $\begin{array}{l}\text { Q.12: I use reading strategies when I do English } \\
\text { reading tests. }\end{array}$ & 1 & 1 & 5 & 4.9 & 25 & 24.3 & 61 & 59.2 & 11 & 10.7 \\
\hline $\begin{array}{l}\text { Q.13: I adjust my learning strategies if I find } \\
\text { they are not suitable for me. }\end{array}$ & 0 & 0 & 1 & 1 & 22 & 21.4 & 71 & 68.9 & 9 & 8.7 \\
\hline $\begin{array}{l}\text { Q.14: I evaluate my learning outcomes in order } \\
\text { to find the problems of my study. }\end{array}$ & 1 & 1 & 2 & 1.9 & 35 & 34 & 52 & 51.5 & 13 & 12.6 \\
\hline $\begin{array}{l}\text { Q.15: I find opportunities to learn English out } \\
\text { of class. }\end{array}$ & 0 & 0 & 0 & 0 & 34 & 33 & 54 & 52.4 & 15 & 14.6 \\
\hline $\begin{array}{l}\text { Q.16: I am able to make full use of the available } \\
\text { learning resources. }\end{array}$ & 1 & 1 & 1 & 1 & 39 & 37.9 & 56 & 54.4 & 6 & 5.8 \\
\hline $\begin{array}{l}\text { Q.17: I try to use the new knowledge when I } \\
\text { practice my English. }\end{array}$ & 0 & 0 & 2 & 1.9 & 35 & 34 & 52 & 50.5 & 14 & 13.6 \\
\hline $\begin{array}{l}\text { Q.18: I can cooperate and learn together with } \\
\text { my classmates. }\end{array}$ & 2 & 1.9 & 2 & 1.9 & 32 & 31.1 & 56 & 54.4 & 11 & 10.7 \\
\hline $\begin{array}{l}\text { Q.19: I know the reasons why I make mistakes } \\
\text { and will take actions to correct them. }\end{array}$ & 2 & 1.9 & 5 & 4.9 & 21 & 20.4 & 60 & 58.3 & 15 & 14.6 \\
\hline
\end{tabular}

As show in Table 3, it can be claimed that it is completely important to make learning objectives explicit so that students understand specifically what they are suppose to learn. More specificity, this helps to remove confusion and allows the student to better focus on the goals of the lesson. Therefore, in Q.1 60,2 \% of the students admitted that they understood the teacher's teaching objectives and requirements. However, $37 \%$ of them (38/103) could not give exact answers for this question so they decided to held neutral response option. Only 4\% (3/103) of the responses indicated the misunderstanding in the teacher's objectives and requirement.

Apart from the understanding teachers' objectives and requirements, knowing the teachers' purpose also plays a very crucial role due to the fact that students' motivation can only be enhanced when the purpose of learning is promoting their autonomy and this is clearly communicated to students by what teachers say and do. For this reason, when Q.2 is calculated, it is easily seen that knowing the teachers' purposes found to be sufficient with $59.2 \%$ of the total agreements (60/103). Furthermore, $31.1 \%$ of the students who were still confused understanding the purposes so they held the neutral response options. However, $9.8 \%$ of students held the disagreement option. The reason could be explained that there might have a misunderstand between teachers and students, hence it seems to be less be effectively transmitted the purposes.

Similarly, Q.3 and Q.4 discussed about students' the setting-up and representating of English language learning objectives. It can be interestingly noted that, more than $61 \%$ of the participants believed that they are able to set up and realize their learning objectives confidently and while from 26,2 to $35 \%$ of them appeared to be undecided. It is truly said that well-defined and articulated learning objectives are important because they provide students with a clear purpose to focus their learning efforts. Only of few participants held the view that it is quite hard for them to set up their own English language learning objectives with 3.9\% and $9.7 \%$ of disagreements respectively. These students said that they do not have such a long-term vision for their learning purposes, hence they are afraid of making mistake in setting academic goals.

Q.5, Q.6 and Q.7 asked on students' studying plan in which the majority of the students (69\%-73\%) who took the questionnaire believed that they can make a solid study schedule by prioritizing the important subjects and courses they need to study for future better job and then adjust their timetable appropriately and flexibly. In contrast, some of them found difficulties in making their appropriate time-table to study English language due to their learning commitments such as health, part-time work, entertainment, family and so on, thus they hold negative orientations ranging from $2.9 \%$ to $4.9 \%$ respectively.

According to Schumaker and Deshler (1992), a learning strategy is an individual's way of organizing and using a particular set of skills in order to learn content or accomplish other tasks more effectively and efficiently in school as well as in nonacademic settings. Therefore, when asking about language learning strategies in Q.8, 64.1\% of the students claimed that they totally understand and use these strategies in learning skilfully. However, $34 \%$ of the them could not give exact answers for this question so they decided to hold neutral response option and only $1.9 \%$ of the participants chose disagree option.

Q.9, Q.10, Q.11, Q.12 and Q.13 gathered information related to the strategies of communication, reading, writing and listening skills. It can be easily seen that the majority of the students selected both agrees and strongly options, ranging from 58.2 $\%$ and $69.9 \%$ respectively. These students revealed that they know how to use language learning strategies which are very helpful to practise speaking, listening, reading and writing in the language classroom in order to achieve their own educational goals. Furthermore, $24.3 \%$ and $39.8 \%$ of them appeared to be undecided when they were asked whether applying the learning strategies 
in the classroom as well as in the test; even they could not give any reasons of their choices. However, there were some minor disagreements about learning strategies with just $1.9 \%$ and $4.9 \%$. Some students explained that even they attended the class regularly and felt very demotivated to set up and employ different strategies to develop their English skill. More importantly, the majority of the participants $(77.6 \%)$ said that they know even know how to adjust their learning strategies if they find not suitable during the learning procedure.

Q.14 asked for the view towards the evaluation of learning outcomes in which $64.1 \%$ of the students admitted that they evaluated their learning outcomes in order to find the problems and then adjust for better for identifying what typically works and what doesn't when authoring learning outcomes of their own. In other words, this evaluation helps students to find out the existing problems in the learning process, based on which students can correct their mistakes. In universities, learners are encouraged to learn English autonomously out of class, for they seldom receive the face-to-face instruction after class. Moreover, for neutral option, the percentage of the students who involved in this study provided uncertain answers for question items was quite high with $34 \%$. In contrast, $2.9 \%$ of the subjects had negative opinions for this question item. One potential reason could be explained for the minor disagreement was that this number of students did not attend class frequently, as the result; they cannot focus on what they expect themselves to be able to demonstrate upon completion of the lesson or course.

Regarding some kinds of opportunities that foster learning autonomy, it can be observed that there are majority of the students who take control and responsibility for their own learning by seeking opportunities to practise English outside the classroom (Q.15-67\%), fully using up the available learning resources (Q.16-60.2\%), using new knowledge when practising English (Q.1764.1\%), learning cooperative classroom (Q.18-65.1\%), fully be aware of recognizing and recorrecting mistakes (Q.19-72.9\%). What is more, $20.4 \%-37.9 \%$ of them confused looking for the best way to learn English, so they decided to hold uncertain answers. Nevertheless, there have been some minor disagreements from those who cannot find their own ways of improving English, ranging from $1.9 \%$ to $4.9 \%$

According to descriptive statistic results above, it has been concluded that students' perceptions on English learning autonomy were on the whole moderately positive ( $\mathrm{M}=3.73, \mathrm{SD}=0.757)$. Furthermore, descriptive statistic of all items (Q.1-Q.19) indicated that more than $50 \%$ of students commented most moderately positive on their learning autonomy in term of understanding teachers' teaching objectives, requirements, purposes; setting-up and representating of English language learning objectives; making and adjusting study plans; using strategies of communication, reading, writing and listening skills; evaluating the learning outcomes and seeking opportunities to practise English inside and outside the classroom. To be more specific, the percentages of agreements of all items range from 59\% to 77\%, in which most of the participants highly agree that they adjusted their learning strategies if these strategies were not suitable for them (77\%); meanwhile most of them moderately agree that they knew the teachers' purposes through different learning activities in order to improve their language skills (59\%). Figure 1 shows the total agreements on students' learning autonomy.

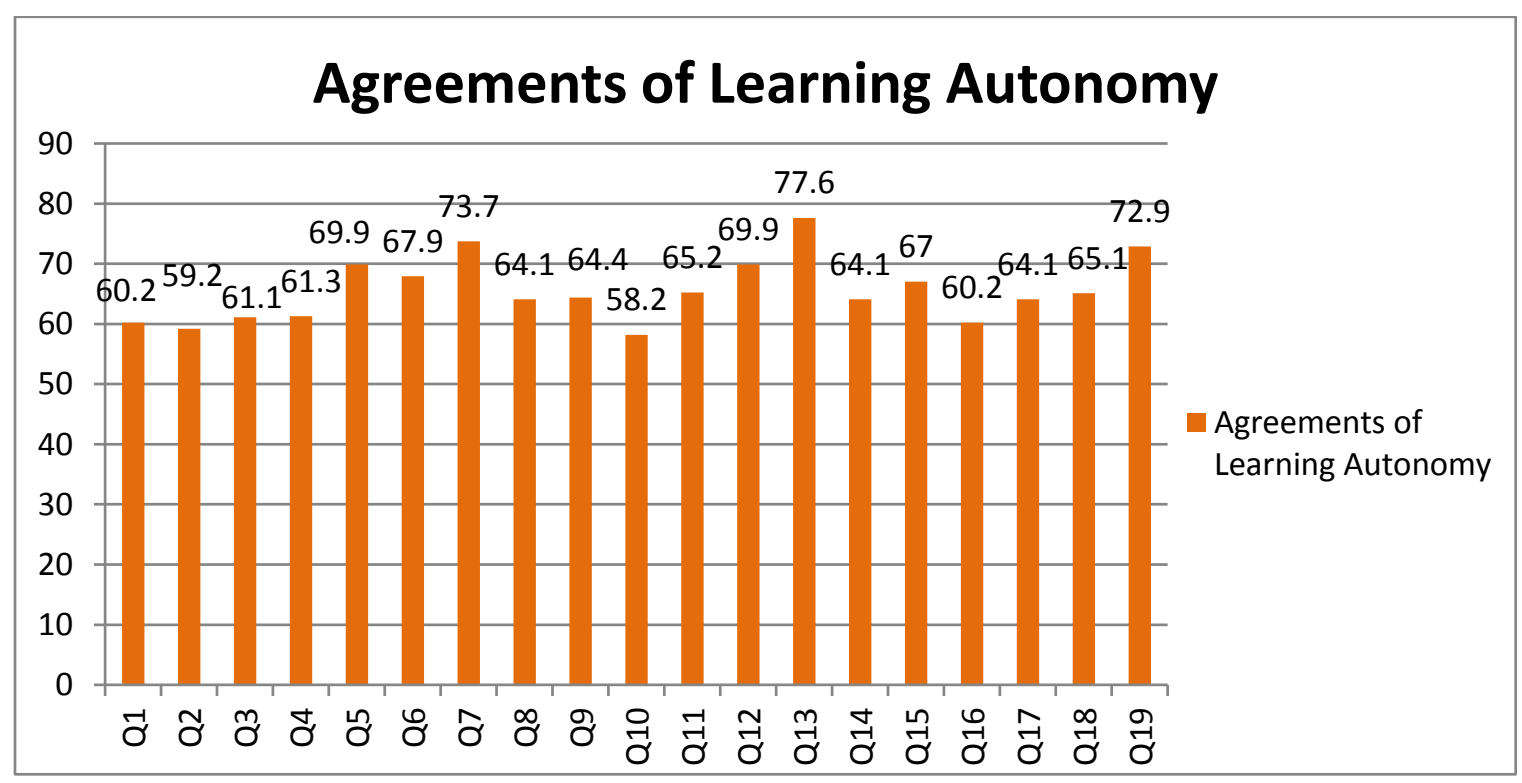

Figure 2. Total agreements on students' learning autonomy

All in all, it can be interestingly noted that the students seem to be able to identify what teachers' purposes, their studying plan, learning strategies and outcomes to master and how to do so efficiently. In other words, they seem to have some aspects of autonomous learning, thus it can be concluded that these participants are considered as autonomous learners. 


\section{Insights into English Non-Major Students' Learning Autonomy at Thai Nguyen University}

\subsection{Factors affect learning autonomy}

Nowadays, with the development of recent modern technologies in a variety of tools such as Facebook, Twitter, Google, Youtube, Zalo and so on, learners have been provided with freedom and openness to communicate with other people around the world in order to become more active and independent in their learning. It is believed, however, that learners, especially Asian learners, seem to possess passive and less autonomous while joining classroom activities so they might not be able to take controls and responsibility for their own learning. Bearing this in mind, this study aims to investigate what factors that have affected learners' autonomy by utilizing the analysis of Pearson Correlation version 24 in to examine the correlations among teachers' purposes and requirements, learning strategies, and learning styles and learner autonomy. In Pearson's correlation, the strength of the relationship is indicated by the correlation coefficient $r$ value. The larger $r$ value is, the stronger of the relationship between two variables is found. The significance of the relationship is expressed by $\mathrm{p}$ - value. The smaller of $\mathrm{p}$ value is, the more significant the relationship between two variables is found. Furthermore, correlation is an effect size and so we can verbally describe the strength of the correlation using the guide which Evans (1996) has suggested for the absolute value of Pearson " $r$ ". Table 5 shows the strength of correlation coefficients.

Table 5. Strength of correlation coefficients

\begin{tabular}{|l|l|}
\hline r- value & Strength of correlation \\
\hline $.00-.19$ & Very weak \\
\hline $.20-.39$ & Weak \\
\hline $.40-.59$ & Moderate \\
\hline $.60-.79$ & Strong \\
\hline $.80-1.0$ & Very strong \\
\hline
\end{tabular}

Table 6. shows the relationship between learning autonomy and teachers' purposes and requirements, learning strategie and learning styles.

\begin{tabular}{|l|l|l|l|}
\hline & $\begin{array}{l}\text { Teachers' objectives } \\
\text { and requirements }\end{array}$ & Learning styles & $\begin{array}{l}\text { Learning } \\
\text { strategies }\end{array}$ \\
\hline & $\begin{array}{l}.423^{* *} \\
(\mathrm{p}=.000)\end{array}$ & & \\
\hline Learning autonomy & & $\begin{array}{l}.335^{* *} \\
(\mathrm{p}=.000)\end{array}$ & \\
\hline & & & $\begin{array}{l}.309^{* *} \\
(\mathrm{p}=.006)\end{array}$ \\
\hline
\end{tabular}

**Correlation is significant at the 0.01 level (2-tailed)

Table 6 is presented graphically in Figure 2 which presents path loadings which are derived from the relationship between learning autonomy and teachers' objectives and requirements, learning styles and learning strategies.

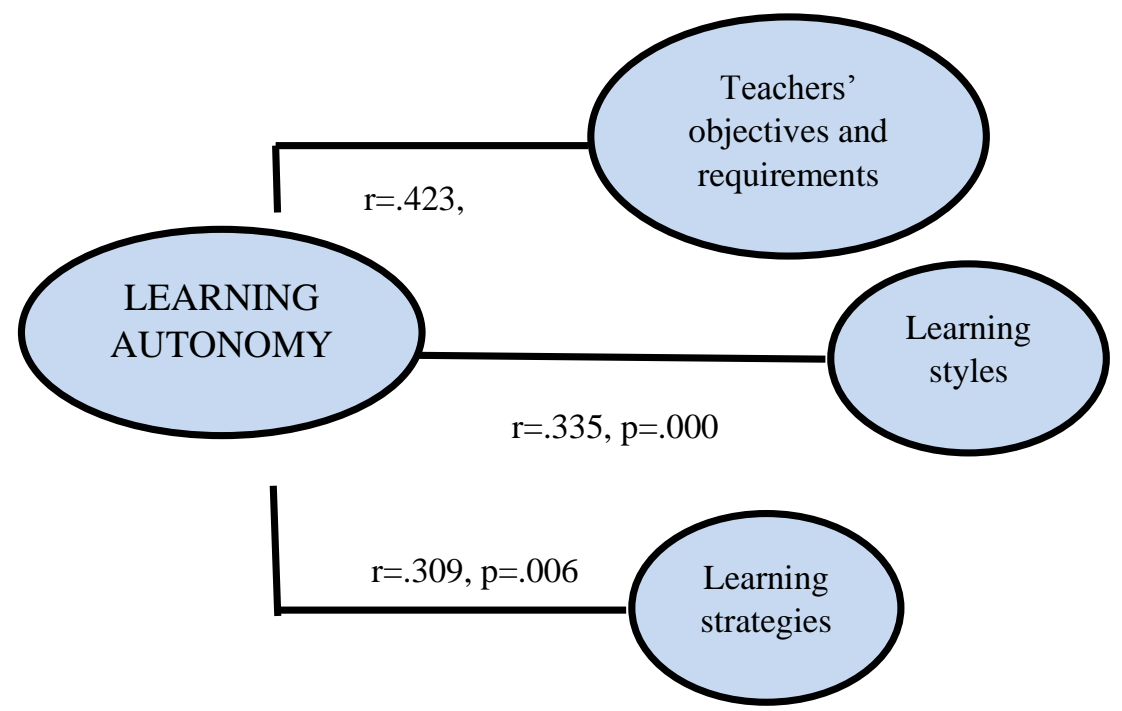

Figure 2. Path loadings for correlation results between learning autonomy and teachers' objectives and requirements, learning styles and learning strategies. 
Results presented in both Table 5 and Figure 1 show that the relationship between learning autonomy and teachers' objectives and requirements, learning styles and learning strategies is significant. The p-value is less than 0.01 level, showing significant correlations among each variable. In addition, the r-value, which ranges from .309 to .423 , is all positive, indicating from weak to moderate correlations. More specifically, the highest correlation is found for teachers' objectives and requirements $(\mathrm{r}=.423)$, followed closely by learning styles ( $\mathrm{r}=.335)$ and learning strategies $(\mathrm{r}=.309)$.

In short, learning autonomy correlates with teachers' objectives and requirements, learning styles and learning strategies significantly. The highest correlation is for the relationship between learning autonomy and teachers' objectives and requirements, followed closely by the association with learning styles and learning strategies. This implies that compared to learning styles and strategies, teachers' objectives and requirements are considered as the most influence factors that affect students' learning autonomy. Therefore, it is suggested that, the higher being awareness of understanding teacher's purposes and requirements and better knowing how to create learning styles and adjust learning strategies students are, the more autonomous they are.

\section{CONCLUSION}

Overall, it can be interestingly observed that there are significant correlations between learning autonomy and teachers' objectives and requirements, learning styles and learning strategies. The strength of correlations is positive and moderate, ranging from .309 to .423 . The strength of correlations is positive and moderate, ranging from .309 to .423 . From the results above, the factors which are teachers' objectives and requirements, learning styles and learning strategies have influenced moderately in students' learning autonomy. Among these factors, the understanding of teachers' objectives and requirements ranks first, then learning styles and strategies take turn the second and third places.

In order to increase learners' learning autonomy, this study recommends further research to be investigated in other factors such as family back ground, gender, motivation, feelings and so on to deeply understand which factor has most influencing on their learning autonomy as well to motivate them to be less dependent on teacher-centred learning. This study also highly recommends that teaching system in Vietnamese universities should be innovated by upgrading activities, modern technology such as audiovisual system, multimedia projectors, computer-based or online English learning activities inside and outside classroom.

\section{REFERENCES}

1) Bednar, A. K., Cunningham, D., Duffy, T. M., \& Perry, J. D. (1991). Theory into practice: How do we link? In G. J. Anglin (Ed.), Instructional technology: Past, present, and future. Englewood, CO: Libraries Unlimited.

2) Bloom, B. S., Engelhart, M. D., Furst, E. J., Hill, W. H., \& Krathwohl, D. R. (Ed.). (1956). Taxonomy of educational objectivities: The classification of educational goals. Handbook I: Cognitive domain. New York: David McKay.

3) Bower, G. H., \& Hilgard, E. R. (1981). Theories of learning ( $5^{\text {th }}$ ed.). Englewood Cliffs, NJ: Prentice-Hall.

4) Brown, J. S., Collins, A., \& Duguid, P. (1989). Situated cognition and the culture of learning. Educational Researcher, $18(1), 32-42$.

5) Clancey, W. J. (1986). Review of Winograd and Flores' understanding computers and cognition: A favorable interpretation. (STAN-CS-87-1173) Palo Alto, CA: Department of Computer Science, Stanford University.

6) Corbin, J., \& Strauss, A. (2008). Basics of Qualitative Research: Techniques and Procedures for Developing Grounded Theory ( $3^{\text {rd }}$ ed.). Thousand Oaks, CA: Sage.

7) Denzin, N. K. \& Y. S. Lincoln (ed.). (2005b). The Sage Handbook of Qualitative Research (3 ${ }^{\text {rd }}$ ed.). Thousand Oaks, Calif: Sage.

8) Dörnyei, Z. (2003). Questionnaires in Second Language Research: Construction, Administration, and Processing. Mahwah, N.J.: Lawrence Erlbaum.

9) Dörnyei, Z. \& Ryan, S. (2015). The Psychology of Language Leaner Revisited. Routledge. Taylor and Francis. New York.

10) Evans, J. D. (1996). Straightforward statistics for the behavioral sciences. Pacific Grove, CA: Brooks/Cole Publishing.

11) Gardner, R.C. and Lambert, W.E. (1972). Attitudes and Motivation in Second Language Learning. Rowley, MA: Newbury House.

12) Guba, E. G., \& Lincoln, Y. S. (1994). Competing paradigms in qualitative research. In N. K. Denzin \& Y. S. Lincoln (Eds.). Handbook of qualitative research (pp. 105-117). Thousand Oaks, CA: Sage.

13) Griffiths, C. (2008). Lessons from Good Language Learners (Ed.). Cambridge University Press. (CUP).

14) Jonassen, D. H. (1991a). Evaluating constructivistic learning. Educational Technology, 31(9), 28-33.

15) Jonassen, D. H. (1991b). Objectivism vs. constructivism: Do we need a new philosophical paradigm. Educational Technology Research and Development, 39(3), 5-14.

16) Jordan, A., Carlile, O., \& Stack, A. (2008). Approaches to Learning - A Guide for Teachers. McGraw Hill Open University Press.

17) Lightbown, P. \& Spada, N. (2001). "Factors Affecting Second Language Learning” In Candlin C. \& Mercer N. English Language Teaching in its Social Context London: Routledge pp. 28-43. 


\section{Insights into English Non-Major Students' Learning Autonomy at Thai Nguyen University}

18) Lightbown, P.M. \& Spada, N. (2013). How Languages are Learned. Oxford University Press.

19) Mayer, R. E. (2002). The promise of educational psychology, Volume 2: Teaching for meaningful learning. Upper Saddle River, NJ: Merrill Prentice Hall.

20) Mitchell, R. \& Myles, F. (2001). Second Language Learning: Key Concepts and Issues. In Candlin C. and Mercer N. English Language Teaching in its Social Context London: Routledge pp. 11-27.

21) Naiman, N., Fröhlich, M. \& Stern, H. et. al. (1978). The Good Language Learner. Clevedon: Multilingual Matters Ltd.

22) Petty, G. (2009). Teaching Today - A Practical Guide (4th ed.). Nelson Thornes. Ltd. United Kingdom.

23) Pritchard, A. (2009). Ways of Learning: Learning Theories and Learning Styles ( $2^{\text {nd }}$ ed.). Routledge, New York.

24) Richards, J.C. (2006). Communicative Language Teaching Today. Cambridge University Press.

25) Rubin, J. (1975). What the 'Good Language Learner' Can Teach Us. TESOL Quarterly 9(1), pp. 41-51.

26) Shuell, T. J. (1986). Cognitive conceptions of learning. Review of Educational Research, 56, 411-436.

27) Schumaker, J. B., \& Deshler, D. D. (1992). Validation of learning strategy interventions for students with LD: Results of a programmatic research effort. In Y. L. Wong (Ed.), Contemporary intervention research in learning disabilities: An international perspective. New York: Springer-Verlag.

28) Winne, P. H. (1985). Cognitive processing in the classroom. In T. Husen \& T. N. Postlethwaite (Eds.), The International Encyclopedia of Education (Vol. 2, pp. 795-808). Oxford: Pergamon.

29) Woodlard, J. (2010). Psychology for the Classroom: Behaviourism. Routledge: New York. 